PROBLEMS

OF EDUCATION

IN THE $21^{\text {st }}$ CENTURY

Vol. 79 , No. 6, 2021

956 THE USE OF THE INTERPRETATION OF WORKS OF ART IN PRE-SCHOOL EDUCATION

\author{
Ivana Rochovská, Božena Švábová \\ Catholic University in Ružomberok, Slovakia \\ E-mail: ikrupova@gmail.com, bozenasvab@gmail.com
}

\begin{abstract}
The research focuses on examining the use of the interpretation of works of art in pre-school education in three dimensions - the current state of the use of the interpretation of works of art, the opinions of kindergarten teachers on art, and the opportunities for kindergarten teachers to acquire knowledge about the theory and history of art in their undergraduate training or in other forms of education. The aim of the research was to determine a correlation between the aforementioned variables. 366 kindergarten teachers responded to the items of the self-constructed questionnaire. It has been proven that the current state of the use of the interpretation of works of art in pre-school education can be described as below average, the opportunities for kindergarten teachers to acquire knowledge from the theory and history of art in their pre-graduate training or in other forms of education were lower than average, and the opinions of kindergarten teachers on art can also be described as below average. There is a statistically significant positive correlation between the aforementioned dimensions of the interpretation of works of art in pre-school education.
\end{abstract}

Keywords: empirical experience, kindergarten teacher, pre-school education, works of art

\title{
Introduction
}

Art and its application in education can have a very positive effect on the development of the personality of the individuals learning, as well as their educational results. Plenty of research has shown that art in various forms can bring measurable benefits to learners.

From a research study by Bowen and Kisida (2019), it emerged that the inclusion of art in education has a positive impact on the lives of children, as these children have better educational results, sooner show compassion to others and are more likely to have fewer discipline problems. This study compared a group of children, who were provided with an extended and enhanced art education, with a group of children who were not provided with such an education. Other research has also shown that art education activities have a beneficial effect on the development of self-expression, creativity, and empathy (Dewey, 1919; Ruppert, 2006). Numerous contemporary research studies have found that, from an early age, children show sensitivity towards many aspects of works of art and their creation, and the arts play an increasingly important role in the development of the child (Acer, 2014; Cox, 2005; Barton, 2015; Gardner, 1990; Nevanen et al., 2014; Novaković, 2014).

There is growing evidence within the plenty of international scientific research which suggests that those who participate in culture (not excluding art, whether it be music, dance, film, literature, etc.), have a better state of health and are more satisfied with life than those who are not involved in culture and art (Mowlah et al., 2014).

Research focused on the benefits of visual arts for children has shown that the inclusion of activities focused on visual arts has a positive effect on the development of their critical thinking (Bowen et al. 2014). Tomas (2019) also verified the influence of experimental activities, 
focused upon contemporary visual art, on the development of a child's potential for creativity, as well as their artistic skills.

Research focused on the benefits of music for children has shown the positive effect of music education, not only in awakening the child's interest in music and in the development of musical abilities, but also that practical musical activity gradually leads to further positive changes in various non-musical areas. According to several experiences, active musical activity can also have a positive effect on the behaviour of children and young people (Rochovská et al. 2021). Duke et al. (1997), believed that playing a musical instrument improves certain personality traits of children, such as discipline, concentration, the ability to relax, reliability, responsibility, and a better understanding of one's own personality.

Research on the application of dramatic expression by the methods of creative drama found that its application contributed to coherence in the classroom and had a positive effect on the behaviour of the children. Thus, the importance of applying creative drama as a didactic tool in education was emphasised (Azlina et al. 2021). In connection with creative drama and the development of creativity, the research of Toivanen et al. (2013) can be brought to our attention. In fact, creative drama provides suitable opportunities to support children's creativity. It develops not only individual creativity, but also group creativity in the school environment. Similarly, Momeni et al. (2017) confirmed the development of the creativity of children, aged four to six, using the methods of creative drama. The researchers used the creativity test of JeanLouis Sellier (1977). Švábová (2019) also pointed out the benefits of using dramatic expression among children of a preschool age.

In connection with the trends of contemporary art (not only visual, but also music, literary and dramatic), which uses the procedures of interpretation (appropriation, citation), the inclusion of the problematic of the interpretation of works of art in education in pre-primary education is one of the options of how to make different types of art accessible to children through their own reaction to the works of art, and thus support them especially in the development of creative and critical thinking and cultural literacy.

\section{Research Issue}

Thus, many of the cited studies have confirmed that the inclusion of activities aimed at working with works of art has a positive effect on learners at different levels and types of schools, not excluding children of a pre-school age. However, the interpretive activities in the kindergarten are required to be led by a teacher who is competent both in pedagogy and in art. Bea (2004) found that teachers had important roles in facilitating children's artistic development. It is possible to ask whether kindergarten teachers feel competent in this respect and to what extent they include the topic of the interpretation of works of art in the framework of educational activities in the kindergarten.

According to Bautista et al. (2017) there is limited research focused on documenting what arts-related pedagogical practices look like in actual preschool classroom settings. A search of online research databases indicated that no studies or large-scale surveys had been conducted with kindergarten teachers to assess their opportunities to acquire knowledge from the theory and history of art, nor the degree of use of the interpretation of works of art in preschool education.

The key topic of research was the interpretation of works of art in pre-school education. The research problem was to examine if there is a correlation among the self-reflection of kindergarten teachers on their knowledge of the theory and history of art, the opinions of kindergarten teachers on art and the use of the interpretation of works of art in pre-school education. The examination of this correlation can lead to a better understanding of the interpretation of works of art in pre-school education from the viewpoint of kindergarten teachers. 
Ivana ROCHOVSKÁ, Božena ŠVÁBOVÁ. The use of the interpretation of works of art in pre-school education

PROBLEMS

OF EDUCATION

IN THE $21^{\text {st }}$ CENTURY Vol. 79 , No. 6, 2021

958
The Aim and Hypotheses of the Research

The main aim of the research was to find out the opinions of kindergarten teachers on the use of the interpretation of works of art in pre-school education. The aim of the research resulted in the following goals:

1. To determine whether the opportunities of acquiring knowledge about the theory and history of art among kindergarten teachers affect the level of the use of the interpretation of works of art in pre-school education.

2. To find out whether the opportunities of acquiring knowledge about the theory and history of art among kindergarten teachers affect the level of their opinions on art.

3. To determine whether the level of the kindergarten teachers' opinions on art has an impact on the use of the interpretation of works of art in pre-school education. formulated:

Based on field experience and on previous empirical experience, the hypotheses were

$\mathrm{H}_{1}$ : There is a statistically significant positive correlation between the opportunities of kindergarten teachers to acquire knowledge from the theory and history of art and the degree of use of the interpretation of works of art in pre-school education.

$\mathrm{H}_{2}$ : There is a statistically significant positive correlation between the ability of kindergarten teachers to acquire knowledge from the theory and history of art and their opinions on art.

$\mathrm{H}_{3}$ : There is a statistically significant positive correlation between the opinions of kindergarten teachers on art and the rate of use of the interpretation of works of art in pre-school education.

\section{Research Methodology}

\section{General Background}

The research was carried out from January 2019 to April 2021, as part of a project, "The interpretation of works of art in pre-school education". Quantitative and qualitative approaches were applied in this project. The project focused on the creation and validation of an instrument for the examination of the current state of the use of the interpretation of works of art in preschool education, the opinions of kindergarten teachers on art and their opportunities to acquire knowledge of the history of art in their undergraduate training or other forms of education. The questionnaire, semi-structured interview and unstructured observation of educational activities focused on the use of works of art in the kindergarten were used in the research.

\section{Sample}

The research sample consisted of 366 kindergarten teachers in Slovakia. Teachers who showed a willingness to participate in the research were chosen for the selection sample; therefore, it constitutes an available selection.

A total of 377 questionnaires were received (via a Google.Docs form and in paper form). A thorough inspection excluded 8 questionnaires, as nothing was filled in and they were sent blank. Another three questionnaires were excluded due to replication.

352 respondents were female, one was male and 13 did not state. The age was stated by a total of 346 kindergarten teachers. The age ranged from 20 years to 64 years, the average age is $M=42.75$ years $(S D=11.79)$. A total of 344 kindergarten teachers stated the number of years of pedagogical praxis. The number of years of pedagogical praxis ranged from 0 years to 46 years, the average number of years of praxis is $M=19.64$ years $(S D=14.29) .57 .9 \%$ of respondents were from municipal kindergartens, $36.3 \%$ of respondents from rural kindergartens, and the remaining 5.7\% of respondents did not state. Most respondents $(91.3 \%)$ were from state kindergartens, $2.2 \%$ were from private kindergartens and $1.6 \%$ from church kindergartens. 


\section{Instruments and Procedures}

PROBLEMS

OF EDUCATION

IN THE $21^{\text {st }}$ CENTURY

Vol. 79, No. 6, 2021

959

To meet the aim of the research, a questionnaire was chosen, with the aim of collecting data from the largest number of respondents as possible in the shortest possible time. A selfconstructed research tool was used. It consisted of three parts. The first part of the questionnaire (Part A) was related to the respondents' opinions on the current state of the use of the interpretation of works of art in pre-school education. In the second part (Part B), the respondents' opportunities to acquire knowledge from the theory and history of art were determined. In the third part (Part C) the respondents' opinion on art was determined. In addition to this, sociodemographic information was determined.

The questionnaire contained a total of 32 questions, whereby the first part was related to 7 scored items, the second part 5 scored items, and 4 scored items in the third part. An exploratory factor analysis was used to determine the factor structure of the three variables. A one-factor solution was confirmed in all three variables. For the variable, "the use of the interpretation of works of art in pre-school education", the internal consistency was $\alpha=.679$, for the variable, "the opportunity to acquire knowledge from the theory and history of art", it was $\alpha=.551$ and for the variable, "the opinions of the teacher on art", $\alpha=.577$.

For Part A - "the current state of the use of the interpretation of works of art in preschool education", the respondent was able to obtain a maximum of 104 points. In Part A, the scoring of answers in the questionnaire was designed so that a higher overall score suggests a greater level of, and a more frequent use of, various works of art by kindergarten teachers, more sources of topics, sufficient publications, and a greater interest from the children, etc.

In the first semi-closed item, the respondents answered whether they used works of art or their reproductions, in educational activities with the children, while choosing from the options a) paintings, sculptures, b) musical compositions, c) theatre performances, d) literary works, e) other, and they were asked to indicate which ones specifically for each option. For each circled answer a) to e), the respondent could get one point.

In the second item, with a simple selection, the respondents indicated how often they included work with various works of art within the kindergarten educational activities, namely in the area of fine/visual art, music art, literary art, dramatic art and other types of art (they were supposed to state which specifically). They were choosing from the options, according to which they also received scores for the answers: a) every day (5 points), b) at least once a week (4 points, c) at least once a month ( 3 points), d) at least once every six months ( 2 points), e) at least once a year (1 point), f) not at all (0 points), g) another answer (they were supposed to state specifically, while being scored individually with a maximum possible number of 5 points).

The third multi-selection item considered in which of the educational areas did the respondents apply activities focused on the interpretation of works of art. The respondents were supposed to mark one or more options a) - g), each option indicated one educational area from a valid curricular document: Language and Communication, Mathematics and Work with Information, Man and Nature, Man and Society, Art and Culture, Man and the World of Work, Health and Exercise. One point was awarded for each specified area.

The fourth item with multiple selections was aimed at drawing suggestions from the respondents for working with a work of art, namely in the area of fine/visual art, music art, literary art, dramatic art, and other types of art (they were supposed to state which specifically). They were choosing from the following options: a) from literature, b) from the Internet, c) from colleagues, d) from conferences and professional seminars and workshops, e) from various forms of continual education, f) I came up with my own one, g) another answer (they were supposed to specify). One point was awarded for each option specified.

In the fifth semi-closed item, the respondents expressed whether they had sufficient methodological materials and publications, related to working with works of art in pre-school 
Ivana ROCHOVSKÁ, Božena ŠVÁBOVÁ. The use of the interpretation of works of art in pre-school education

PROBLEMS

OF EDUCATION

IN THE $21^{\text {st }}$ CENTURY Vol. 79, No. 6,2021

960

education, at their disposal in their kindergarten, namely in the area of fine/visual art, music art, literary art, dramatic art, and other types of art (they were supposed to state which specifically). They were supposed to mark one of the options: a) yes, b) no, c) another answer (they were supposed to specify). They received one point for each answer marked "yes". Option c) was scored individually, but they could get a maximum of one point. In order to obtain a more objective picture about whether there were sufficient publications with the aforementioned focus, the respondents were supposed to state the approximate number of publications available in the kindergarten for each type of art.

In the sixth item, the respondents stated with a simple selection of how interested the children were in working with works of art within educational activities, namely in the area of fine/visual art, music art, literary art, dramatic art, other types of art (they were supposed to state which specifically). They were choosing from options, according to which they also received scores for the answers: a) great interest (4 points), b) interest (3 points), c) neither interest nor disinterest ( 2 points), d) mostly disinterest (1 point), absolute disinterest ( 0 points).

The seventh open item focused on whether the respondents used innovative methods (e.g., role-plays, creative drama, research methods) when working with works of art in the kindergarten, and which ones specifically. They received 1 point for each aforementioned innovative method, the maximum possible number of points obtained for answering this question was 7 points.

For Part B - "opportunities for teachers to acquire knowledge from the theory and history of art", the respondent could get a maximum of 55 points. The scoring of the answers in the questionnaire in Part B was designed so that the more points the respondent obtained, the better their self-reflection on education in the area of art (knowledge, practical artistic activity, theoretical, methodological and practical ideas for carrying out activities with children in the kindergarten connected with art).

The first multiple-choice item focused on the evaluation of the ability of the respondent to acquire knowledge from the theory and history of art during their studies, in the area of fine/ visual art, music art, literary art, dramatic art and other types of art (they were supposed to state which specifically). They were choosing from options, according to which they also received scores for the answers: a) excellent (4 points), b) very good (3 points), c) good (2 points), d) sufficient (1 point), e) insufficient ( 0 points).

In the second multiple-choice item, the respondents were asked to mention some specific disciplines they had attended in high school or university, in the area of fine/visual art, music art, literary art, dramatic art and other types of art (they were supposed to state which specifically). They were choosing from options, according to which they also obtained scores for the answers: a) yes, during high school studies (1 point), b) yes, during university studies (1 point), c) no ( 0 points), d) I do not remember (0 points).

The third semi-closed item focused on finding out whether the respondents acquired knowledge from the theory and history of art, even after completing undergraduate training in the form of continuous, or non-formal or informal education (various courses, workshops, conferences, etc.). They were choosing from options, according to which they also received a score for the answers: a) yes, in the form of continuous education ( 1 point), b) yes, in the form of non-formal education (e.g. courses, workshops) (1 point), c) yes, in the form of informal education (spontaneously acquired knowledge) (1 point), d) no (0 points), other answer (they were supposed to state specifically, while being scored individually, with the maximum possible number of acquired points 1 ).

In the fourth item, the respondents were supposed to indicate whether they had attended any courses, workshops or seminars aimed at getting acquainted with art or practical artistic activities, (e.g., courses of painting, ceramics, dancing, theatre...), namely in the area of fine/ visual art, music art, literary art, dramatic art, and other types of art (they were supposed to state 
which specifically). For each type of art, they were supposed to give at least an approximate name, whereby for each given name of a course, workshop or seminar within one type of art, 1 point was awarded, so it was possible to get a maximum of 5 points for the entire item.

In the fifth item, the respondents were supposed to state whether they had completed any courses, workshops or seminars focused on theoretical, methodological or practical topics, and how to implement activities with children in the kindergarten to learn about works of art, namely in the area of fine/visual art, music art, literary art, dramatic art and other types of art (they were supposed to state which specifically). For each type of art, they were supposed to state at least an approximate name, with 1 point awarded for each given name of the course, workshop or seminar within one type of art, but a maximum of 5 points could be obtained for the entire item.

For Part C - "the opinions of the kindergarten teachers on art", the respondent could obtain a maximum of 71 points. The scoring of the answers in the questionnaire in Part $\mathrm{C}$ was designed so that the more points the respondent obtained, the more important art was for her, and the more active she was in art or aesthetic activities, not only passively as a recipient, but also actively.

In the first multiple-choice item, the respondents answered whether they considered art to be important in their lives, especially the area of fine/visual art, music art, literary art, dramatic art and other types of art (they were supposed to state which specifically). They were choosing from options, according to which they also received scores for the answers: a) very significant (4 points), b) significant (3 points), c) partly significant (2 points), d) mostly insignificant (1 point), e) not significant at all ( 0 points).

The second multiple-choice item focused on how often respondents visited different institutions and performances - art galleries and museums, classical music concerts, literary cafes, theatre performances, ballet/musical/opera/operetta, and other art presentations (they had the opportunity to add three other events or institutions they attended). They were choosing from the options according to which they also received scores for answers: a) at least once a week (4 points), b) at least once a month ( 3 points), c) at least once every six months ( 2 points), d) at least once a year (1 point), e) never (0 points).

In the third semi-enclosed item, the respondents were supposed to circle the statements that best described them: a) I have artistic paintings/sculptures or their reproductions in my home (they were supposed to indicate which ones specifically); b) I own musical instruments (they were supposed to indicate which ones specifically); c) I have art literature in my library (they were supposed to indicate which ones specifically); d) I own video recordings of theatre performances (they were supposed to indicate which ones specifically); e) I own other art or art-related objects (they were supposed to indicate which ones specifically). One point was awarded for each marked statement.

The fourth multiple-choice item was focused on whether respondents were actively involved in artistic creation, indicating one option for each question, and being awarded points a) yes, often ( 2 points), b) yes, occasionally ( 1 point), c) never ( 0 points). The questions were as follows: Are you actively involved in drawing/painting/sculpture? Do you play a musical instrument? Which one? Do you write poems/prose? Do you act in the theatre? The respondents could also provide another related answer regarding their artistic/aesthetic work.

In the form in which the questionnaire is compiled (its individual parts are not unidimensional and include within them several factors of the observed occurrence, it is more focused on a description of the occurrence), it is difficult to analyse its validity and reliability. On the other hand, with a questionnaire designed in this way, focused on a description of the occurrence, it is not even necessary to monitor its validity and reliability. Based on the preliminary research, an analysis of the items was applied, on the basis of which the quality of the items was evaluated, and possible modifications were proposed (which were minimal in this case). 
Ivana ROCHOVSKÁ, Božena ŠVÁBOVÁ. The use of the interpretation of works of art in pre-school education

PROBLEMS

OF EDUCATION

IN THE $21^{\text {st }}$ CENTURY

Vol. 79, No. 6,2021

Data collection took place from 20th June 2019 to 30 th September 2020. The questionnaire was administered in several ways - on the one hand, it was sent by e-mail to kindergartens with a link to an electronic form of the questionnaire. The lowest return was expected here, given that kindergarten employees are burdened with administrative obligations to such an extent that they often do not respond at all to requests to complete a questionnaire. The questionnaire was also administered through social groups, where a slightly higher return was expected due to the fact that not only managers but also teachers are registered, who to a greater extent work directly with the children. The highest return expected for the questionnaires, was for those which were administered in person, in paper form. The return cannot be calculated as a percentage, as the real data can only be found in questionnaires administered in person, and it is not possible to verify exactly how many teachers opened the e-mail with a link to the questionnaire, or how many teachers from these social groups were registered at the time of the request of its completion.

\section{Data Analysis}

The data were analysed using the Jamovi program. Basic descriptive characteristics such as $n, M, S D, M d n, M o$, minimum and maximum were determined. An exploratory factor analysis was used to determine the factor structure of the generated variables. Internal consistency was determined by Cronbach's alpha coefficient, and linear regression was used to verify the hypotheses.

\section{Research Results}

Current State of the Use of the Interpretation of Works of Art in Pre-school Education

The average value of the use of the interpretation of works of art in pre-school education is $M=46.7(S D=13.4)$ and the median is $M d n=47$. Values ranged from 0 to 91 .

Table 1

Basic Descriptive of the Outcome of Part A of the Questionnaire

\begin{tabular}{lllllll}
\hline $\boldsymbol{n}$ & $\boldsymbol{M}$ & Mdn & Mo & SD & $\min$ & $\max$ \\
\hline 366 & 46.7 & 47 & 47 & 13.4 & 0 & 91 \\
\hline
\end{tabular}

Based on the description, the current state of the use of the interpretation of works of art in pre-school education can be described as lower than the scale average (scale range from 0 to 99 ).

Opportunities for Kindergarten Teachers to Acquire Knowledge of the Theory and History of Art in their Pre-graduate Training or in Other Forms of Education

The average value for the variable, "opportunity to acquire knowledge from the theory and history of art", was $M=15.7(S D=7.78)$. The median was equal to $M d n=16$. Values ranged from 0 to 40 points. 
Table 2

Basic Descriptive of the Outcome of Part B of the Questionnaire

\begin{tabular}{lllllll}
\hline $\boldsymbol{n}$ & $\boldsymbol{M}$ & Mdn & Mo & SD & $\min$ & $\max$ \\
\hline 366 & 15.7 & 16 & 20 & 7.78 & 0 & 40 \\
\hline
\end{tabular}

Based on the above description of the variable, the opportunities for kindergarten teachers to acquire knowledge of the theory and history of art in their pre-graduate training or in other forms of education are lower than average (the range of the scale is from 0 to 55).

\section{The Opinions of Kindergarten Teachers on Art}

The average value of the variable, the opinions of teachers on art, was $M=21.6(S D=$ 7.78) and with a median $M d n=22$. Values ranged from 0 to 46 points.

\section{Table 3}

Basic Descriptive of the Outcome of Part C of the Questionnaire

\begin{tabular}{lllllll}
\hline $\boldsymbol{n}$ & $\boldsymbol{M}$ & Mdn & Mo & SD & $\min$ & $\max$ \\
\hline 366 & 21.6 & 22 & 22 & 8.39 & 0 & 46 \\
\hline
\end{tabular}

Based on the above description (range of points from 0 to 71 ), the opinions of kindergarten teachers on art are rather low (based on average values and the median).

\section{Verification of Hypothesis $H_{1}$}

Hypothesis $\mathrm{H}_{1}$ assumed that there is a statistically significant positive correlation between the opportunities of kindergarten teachers to acquire knowledge from the theory and history of art and the degree of use of the interpretation of works of art in pre-school education. There is a statistically significant positive correlation between the variables, which is moderately strong $r=0.486(p<.0001)$. The coefficient of determination is $R^{2}=0.236$, that is to say $23.6 \%$ of the variance in the use of the interpretation of works of art in pre-school education is explained by the opportunities of acquiring knowledge of the theory and history of art among teachers. The regression model predicts well the use of the interpretation of works of art in pre-school education, based on the opportunity of acquiring knowledge from the theory and history of art $(F(1.364)=112.628, p<.0001)$. Hypothesis $\mathrm{H}_{1}$ was confirmed.

\section{Table 4}

Additional Information to Verify Hypothesis $H_{1}$

\begin{tabular}{|c|c|c|c|c|c|c|c|}
\hline & \multicolumn{2}{|c|}{$\begin{array}{l}\text { Unstandardised } \\
\text { Coefficients }\end{array}$} & \multirow{3}{*}{$\beta$} & \multirow{2}{*}{$t$} & \multirow{2}{*}{$p$} & \multicolumn{2}{|c|}{$95 \% \mathrm{Cl}$ interval } \\
\hline & $B$ & $S E$ & & & & $\begin{array}{l}\text { Lower } \\
\text { Bound }\end{array}$ & $\begin{array}{l}\text { Upper } \\
\text { Bound }\end{array}$ \\
\hline (Constant) & 33.542 & 1.387 & & 24.188 & $<.0001$ & 30.815 & 36.269 \\
\hline $\begin{array}{l}\text { Opportunities } \\
\text { to Acquire } \\
\text { Knowledge }\end{array}$ & 0.838 & 0.079 & 0.486 & 10.613 & $<.0001$ & 0.683 & 0.994 \\
\hline
\end{tabular}


Ivana ROCHOVSKÁ, Božena ŠVÁBOVÁ. The use of the interpretation of works of art in pre-school education

PROBLEMS

OF EDUCATION

IN THE $21^{\text {st }}$ CENTURY

Vol. 79, No. 6,2021

964

This means that if kindergarten teachers have enough opportunities to acquire knowledge of the theory and history of art, this will then be reflected in the increased use of the interpretation of works of art in pre-school education. On the other hand, if they use interpretive activities in pre-school education, it forces them to focus more on art and study it.

\section{Verification of Hypothesis $\mathrm{H}_{2}$}

Hypothesis $\mathrm{H}_{2}$ assumed that there is a statistically significant positive correlation between the ability of kindergarten teachers to acquire knowledge from the theory and history of art and their opinions on art. There is a statistically significant positive correlation between the variables, which is moderately strong $r=0.569(p<.0001)$. The coefficient of determination is $R^{2}=0.324$, that is to say $32.4 \%$ of the variance in the level of the teacher's opinions on art is explained by the opportunities of acquiring knowledge of the theory and history of art among teachers. The regression model predicts well the opinions of teachers on art based on the opportunities of acquiring knowledge from the theory and history of art $(F(1.364)=174.314$, $p<.0001)$. Hypothesis $\mathrm{H}_{2}$ was confirmed.

Table 5

Additional Information to Verify Hypothesis $\mathrm{H}_{2}$

\begin{tabular}{|c|c|c|c|c|c|c|c|}
\hline & \multicolumn{2}{|c|}{$\begin{array}{l}\text { Unstandardised } \\
\text { Coefficients }\end{array}$} & \multirow{2}{*}{$\beta$} & \multirow{2}{*}{$t$} & \multirow{2}{*}{$p$} & \multicolumn{2}{|c|}{$95 \% \mathrm{Cl}$ interval } \\
\hline & $B$ & SE & & & & $\begin{array}{l}\text { Lower } \\
\text { Bound }\end{array}$ & $\begin{array}{l}\text { Upper } \\
\text { Bound }\end{array}$ \\
\hline (Constant) & 11.979 & 0.817 & & 14.67 & $<.0001$ & 10.373 & 13.585 \\
\hline $\begin{array}{l}\text { Opportunities } \\
\text { to Acquire } \\
\text { Knowledge }\end{array}$ & 0.614 & 0.047 & 0.569 & 13.203 & $<.0001$ & 0.523 & 0.705 \\
\hline
\end{tabular}

This means that if kindergarten teachers have enough opportunities to acquire knowledge of the theory and history of art, it will also be reflected in their opinions on art, they will gain better opinions on it. On the other hand, if they have positive opinions on art and its discovery, it motivates them to acquire additional knowledge, perhaps through continual education, or various courses and workshops which are currently on offer.

\section{Verification of Hypothesis $\mathrm{H}_{3}$}

Hypothesis $\mathrm{H}_{3}$ assumed that there is a statistically significant positive correlation between the opinions of kindergarten teachers on art and the rate of use of the interpretation of works of art in pre-school education. There is a statistically significant positive correlation between the variables, which is moderately strong $(r=0.395, p<.0001)$. The coefficient of determination is $R^{2}=0.156$, that is to say $15.6 \%$ of the variance in the use of the interpretation of works of art in pre-school education is explained by the level of the teacher's opinions on art. The regression model predicts well the use of the interpretation of works of art in pre-school education, based on the opinions of kindergarten teachers on $\operatorname{art}(F(1.364)=67.174, p<.0001)$. Hypothesis $\mathrm{H}_{3}$ was confirmed. 
Table 6

Additional Information to Verify Hypothesis $\mathrm{H}_{3}$

\begin{tabular}{|c|c|c|c|c|c|c|c|}
\hline & \multicolumn{2}{|c|}{$\begin{array}{l}\text { Unstandardised } \\
\text { Coefficients }\end{array}$} & \multirow{2}{*}{$\beta$} & \multirow{2}{*}{$t$} & \multirow{2}{*}{$p$} & \multicolumn{2}{|c|}{$95 \% \mathrm{Cl}$ interval } \\
\hline & $B$ & $S E$ & & & & $\begin{array}{l}\text { Lower } \\
\text { Bound }\end{array}$ & $\begin{array}{l}\text { Upper } \\
\text { Bound }\end{array}$ \\
\hline (Constant) & 33.087 & 1.786 & & 18.521 & $<.0001$ & 29.574 & 36.6 \\
\hline $\begin{array}{l}\text { Opinions of } \\
\text { Kindergarten } \\
\text { Teachers on Art }\end{array}$ & 0.631 & -0.077 & 0.395 & 8.196 & $<.0001$ & 0.479 & 0.782 \\
\hline
\end{tabular}

This means that if kindergarten teachers have positive opinions on art, it increases the rate of use of the interpretation of works of art in pre-school education. On the other hand, if they use interpretive activities in pre-school education, their opinions on art are even better.

\section{Discussion}

The main aim of the research was to find out the opinions of kindergarten teachers on the use of the interpretation of works of art in pre-school education. It was confirmed that there is a statistically significant positive correlation between the opportunities of kindergarten teachers to acquire knowledge from the theory and history of art and the degree of use of the interpretation of works of art in pre-school education. Furthermore, it was confirmed that there was a statistically significant positive correlation between the ability of kindergarten teachers to acquire knowledge from the theory and history of art and their opinions on art. It was also found that there was a statistically significant positive correlation between the opinions of kindergarten teachers on art and the rate of use of the interpretation of works of art in pre-school education.

In curricular documents for pre-school education, scope is devoted to the interpretation of works of art. With the exception of less than $1 \%$ of the respondents, each of the interviewed kindergarten teachers commented on the use of works of art within educational activities, but the current state of the use of works of art in pre-school education can be described as below average. Most of them commented on the use of literary works/texts, on the use of musical compositions, theatre performances, and only less than half commented on the use of paintings and sculptures, or their reproductions. Among other types of art, dance and folk artwork were also mentioned. These quantitative answers were specified in more detail (Rochovská et al., 2021) and it turned out that the real numbers would be even lower if the works of so-called "high art", which the teachers reported, were the only ones taken into account.

The question is, why are teachers less inclined to use works of art in education? It turns out that teachers still prefer classical forms and methods in children's education and prefer to work with proven methodological ideas rather than experimenting in the given area and looking for new ways to use the potential of the interpretation of works of art within children's education.

Similarly, from a research study by Novaković (2014) it emerged that, in accordance with the traditional concept, preschool teachers considered their role to be teaching children what and how to draw (Novaković, 2014). Hsiao (2015) also found that parents (as non-professionals in the area) believed that preschool art teachers should have basic drawing skills and be familiar with art supplies and craft equipment.

Teachers who worked with works of art stated that the children were interested in this work. In the area of fine/visual, musical, dramatic and other unspecified types of art, the teachers 
Ivana ROCHOVSKÁ, Božena ŠVÁBOVÁ. The use of the interpretation of works of art in pre-school education

PROBLEMS

OF EDUCATION

IN THE $21^{\text {st }}$ CENTURY Vol. 79 , No. 6, 202

966

expressed the "great interest" shown by the children. Only the area of literary art stands out from the average. The second largest group of teachers generally expressed the "interest" of the children working with works of art. Only a negligible percentage of the teachers indicated "absolute disinterest" or "predominantly disinterest". The opinions of teachers on the children's interest in art are largely influenced by the interest of the teachers themselves in art, or by the importance they give it in their life. The attractiveness of the educational methods applied certainly contributes to the interest of the children. The teachers commented on the use of creative drama and role-playing to a large extent, while a little less so to research methods, brainstorming, experiments, tests, experiential learning methods, and other innovative and active methods. Poneliené and Širiakovienè (2018) found that most of the kindergarten teachers preferred traditional art techniques in visual art education: drawing $(73.1 \%)$, moulding (54.9\%), painting (50.5\%), appliqué (44.5\%), stamping (43.9\%) and other techniques (42.9\%). The research also showed that the teacher must be prepared to individualise the curriculum, and choose attractive, unconventional art techniques and tools. In accordance with the use of innovative methods in art education in pre-school education, research by Yang and Chen (2021), and Nevanen et al. (2014) can be mentioned, which recommended the use of new media and art projects.

The kindergarten teachers involved in the research rated their ability to acquire knowledge of the theory and history of art during their studies as "good" in the area of fine and dramatic art, and as "very good" in the area of music and literary art. Thus, they were aware of their limits. Similarly, Novaković (2014) examined preschool teachers' self-reflection of their knowledge of art. The research results showed that preschool teachers rated their knowledge of the areas of art as "good".

Despite the limitations of the teachers' self-reflection and their ability to acquire the knowledge from the theory and history of art, only a small number of them (approximately onefifth or less) commented on continual, non-formal or informal learning, relying more on selfstudy than on institutional education. That is in accordance with research by Leung (2018), who found out that kindergarten teachers were unprepared for and varied in their implementation of early visual arts teaching at both lower and higher class levels. According to Craw (2015), students of pre-school teacher education, who complete three-years of university studies, have only a few opportunities to develop a deeper and broader knowledge and understanding of the broader contexts from a variety of disciplines, including the arts, as well as within curricular documents, and also have no opportunities to make meaningful links to social and cultural praxis in the arts.

On the contrary, many art teachers do not have a background in early childhood education. The lack of knowledge and pedagogy about art teaching and the isolated teaching of art pose several problems about how art education is included in early childhood curricula and how art is taught to young children. The problem is that teachers' art textbooks focus on early childhood education tend to stress manual activities that promote simple skills and quickly rendered products rather than help children make meaning through art (Ruismäki, Juvonen, 2008).

Kindergarten teachers have said that art plays a role in the significance of their lives. Most consider it "important" (almost half expressed this opinion in each of the four areas of art examined). About a third in the areas of fine art, music art and literary art said that they considered it to be "very significant" in their lives. About a quarter of teachers commented on dramatic art as "very significant". Only a negligible percentage described art as "mostly insignificant" in life, and almost no one said that art was "absolutely insignificant" for them.

With regards to the question about how often they visit institutions and art-related events (museums and galleries, classical music concerts, literary cafes, theatrical performances, etc.), the response was "very rarely". It can be taken positively that each teacher at least had some 
area of art in which they sometimes supported those institutions tasked to present the so-called "high art". No teacher was found who did not mention any of the aforementioned institutions.

In the research (Novaković, 2014), regarding the question about how often teachers implement art activities in a gallery or a museum, $61.8 \%$ of the preschool teachers answered, "very rarely"; $25.1 \%$ "sometimes" use this kind of work, while 13\% of preschool teachers implement art activities in a museum or gallery "often" or "very often".

The opinion of the teachers on art is also evidenced by their opinion about the ownership of art objects. However, perceptions of teachers about the ownership of art objects still differ significantly if the criterion of the art object is "high art" and objects falling into "low art" would not be taken into account.

Similarly, regarding the active artistic creation of the teachers, it is possible to think more from the point of view of an amateur creation and a hobby which, however, testifies about their opinions on art and the effort to utilise the stimuli of art for their aesthetic activities.

The teachers believe that merely providing art materials in early childhood classroom is not a sufficient condition for enhancing children's artistic growth (Bea, 2004). Similarly, Ponelienè and Širiakovienè (2018) found that art activities promoted teacher's originality, selfexpression and creativity.

The research shows that there is a statistically significant positive correlation between the opportunities of kindergarten teachers to acquire knowledge from the theory and history of art and the degree of use of the interpretation of works of art in pre-school education. Similarly, from a research study by Novaković (2014) it emerged that there was a statistically significant correlation between the frequency of including art works in art activities with children and the preschool teachers' opinions about personal knowledge of art history basics (Novaković, 2014).

The research also shows that there is a statistically significant positive correlation between the ability of kindergarten teachers to acquire knowledge from the theory and history of art and their opinions on art. Similarly, from a research study by Novaković (2014) it emerged that there was no statistically significant difference in preschool teachers' opinions on their personal knowledge of visual art, when considering the education degree and professional title. The results also showed no statistically significant difference in the preschool teachers' opinions about their own role in the art activities, with regards to the education degree (Novaković, 2014).

The results of the research can also be compared with the results of interviews with teachers who are known for the application of the interpretation of works of art in kindergartens (Rochovská et al., 2021). In the interview, each of the five teachers answered "yes" to the question of whether she thinks that, thanks to her education in the area of art, she applies activities aimed at interpreting works of art in the kindergarten to a greater extent. Similarly, the teachers stated that their preparedness from the history and theory of art, on the basis of their studies, is very good, they were educated even after graduation; in their free time, they attend events where one can encounter art and are also active in terms of art or aesthetic creation. At the same time, they assessed their opinions on art as being very good. Likewise, each of these teachers answered "yes" to the question of whether they think that, due to their opinions on art, they apply activities aimed at interpreting works of art to a greater extent. One of them added that if she did not have such an intense and personal opinion on art, she would not pay so much attention to the interpretation of works of art in the kindergarten because according to her, it is difficult to prepare and understand as a teacher (to know how to comprehensibly interpret art to children).

The limits of the research are that the completion of the questionnaire was voluntary and was probably completed mainly by teachers who have an opinion on art and felt the need to comment on this topic. Thus, the real situation may be "worse" than described, especially in terms of the current state of the use of art in kindergartens and the opinions of the respondents

\begin{tabular}{|l} 
PROBLEMS \\
OF EDUCATION \\
IN THE 21 $1^{\text {st }}$ CENTURY \\
Vol. 79, No. 6, 2021
\end{tabular} 
Ivana ROCHOVSKÁ, Božena ŠVÁBOVÁ. The use of the interpretation of works of art in pre-school education

PROBLEMS

OF EDUCATION

IN THE $21^{\text {st }}$ CENTURY

Vol. 79, No. 6, 2021

968

on art. Limited to the teachers' answers, it can be considered that every teacher is aware that having a certain positive opinion on art is desirable, from the point of view of carrying out their profession.

\section{Conclusions and Implications}

The research clearly confirmed that the current state of the use of the interpretation of works of art in pre-school education can be described as below average. The opportunities of kindergarten teachers to acquire knowledge of the history of art, in their undergraduate education or other forms of education, was lower than average; and the opinions of kindergarten teachers on art can also be described as below average as well. There is a statistically significant positive correlation between the aforementioned dimensions of the opinions of the kindergarten teachers.

The benefits and recommendations for pedagogical praxis are derived from the research results. It is recommended to increase the awareness of kindergarten teachers about the validity of the topic of art interpretation already in pre-school education, to pay more attention to the didactic use of art and to apply more specific stimuli to the preparation for the profession than to work with art didactically. It is also recommended to increase the competencies of kindergarten teachers in the area of art (especially the knowledge of various artistic directions and techniques, and a broadening and deepening of knowledge from the theory and history of art). This can also be expected to increase the interest of kindergarten teachers in the inclusion of art and its stimuli in aesthetic activities (either as a recipient or a creator) into their lives and into the children's activities in the kindergarten. It is recommended to offer kindergarten teachers methodological guidelines and practical ideas on how to carry out interpretive activities with children in the kindergarten; to provide more teaching aids and materials in kindergartens (books, paintings, musical instruments ...) and methodological publications, thus increasing the material equipment of kindergartens in the area of the interpretation of works of art; to implement elements of the use of art also into the school educational programs of kindergartens, for example by using the work of artists who are from the region, thus also specifying in the regional education the inclusion of the interpretation of works of art from that given region; and to cooperate with primary art schools from the given locality and region, and organise mutual events.

The impetus for further research is to carry out case studies of specific kindergarten teachers, who have begun to deal with the topic, based on suggestions from this project, "Artists in the kindergarten - an interpretation of works of art in pre-school education" and successfully move forward in the implementation of works of art in praxis.

\section{Acknowledgements}

The research was done as part of KEGA project No. 004KU-4/2019 "Artists in the kindergarten - an interpretation of works of art in pre-school education".

\section{Declaration of Interest}

Authors declare no competing interest.

\section{References}

Acer, D. (2014). The arts in Turkish preschool education. Arts Education Policy Review, 116(1), 43-50. https://doi.org/10.1080/10632913.2015.970102 
Azlina, S., Ahmad, M. F., \& Abdullah, Z. (2021). Creative drama as a teaching tool in the classroom. International Journal of Academic Research in Business and Social Sciences, 11(3), 1-6. http://dx.doi.org/10.6007/IJARBSS/v11-i3/8912

Barton, G. (2015). Art-based educational research in the early years. International Research in Early Childhood Education, 6(1), 62-78. https://doi.org/10.4225/03/58100971932F8

Bautista, A, Moreno-Núñez, A., Koh, S. F. Amsah, F, \& Mull, R. (2017). Arts-related practices in preschool education: An Asian perspective. Early Childhood Research Quarterly, 45(4), 277-288. https://doi.org/10.1016új.ecresq.2017.12.005

Bea, J.-H. (2004). Learning to teach visual arts in an early childhood classroom: The teacher's role as a guide. Early Childhood Education Journal, 31(4), 247-254. https://doi.org/10.1023/B:ECEJ.0000024116.74292.56

Bowen, D. H., \& Kisida, B. (2019). Investigating casual effects of arts education experiences: Experimental evidence from Houston's Art access initiative. Rice University's Kinder Institute for Urban Research, 7(4), 1-32. https://ies.ed.gov/ncee/wwc/Study/88827

Bowen, D. H., Greene, J. P., \& Kisida, B. (2014). Learning to think critically: A visual art experiment. Educational Researcher, 43(1), 37-44. https://doi.org/10.3102/0013189X13512675

Cox, M. (2005). The pictorial world of the child. Cambridge University Press.

Craw, J. (2015). Making art matter-ings: Engaging (with) art in early childhood education. In Aotearoa New Zealand. Journal of Pedagogy, 6(2), 133-153. https://doi.org/10.1515/jped-2015-2018

Dewey, J. (1919). Imagination and expression. Teachers College Bulletin, 10(10), 7-15.

Duke, R. A., Flowers, P. J., \& Wolfe, D. E. (1997). Children who study piano with excellent teachers. Bulletin of the Council for Research in Music Education. 132, 51-84.

Gardner, H. (1990). Art Education and human development. The Getty Center for Education in the Arts.

Goodman-Schanz, B. A. (2012). K-1 Teachers' visual art beliefs and their role in the early childhood classroom (Dissertation). The University of Southern Mississippi.

Hsiao, Ch. S. (2015). Current kindergarten parents' attitudes toward and beliefs about children's art education in majority cities and countries of Taiwan. International Education Studies, 8(4). https://doi.org.5539/ies.v8n4p80

Leung, S. (2018). An exploratory study of early visual arts education in two Hong Kong kindergartens. Journal of Research in Childhood Education, 32(4), 392-403. https://doi.org/10.1080/02568543.2018.1498414

Momeni, S., Khaki, M., \& Amini, R. (2017). The role of creative drama in improving the creativity of 4-6 years old children. Journal of History Culture and Art Research, 6(1), 617-626. https://doi.org/10.7569/taksad.v6i1.765

Mowlah, A., Niblett, V., Blackburn, J., \& Harris, M. (2014). The value of arts and culture to people and society - an evidence review. Arts Council England.

Nevanen, S., Juvonen, A, \& Ruismäki, H. (2014). Kindergarten and school as a learning environment for art. International Journal of Education through Art, 10(1), 7-22. https://doi.org/10.1386/eta.10.1.7_1

Novaković, S. (2014). Preschool teacher's role in the art activities of early and preschool age children. Croatian Journal of Education, 17(1), 153-163. https://doi.org/10.15516/cje.v17i01497

Ponelienè, R., \& Širiakovienè, A. (2018). Preschool-age children's education by art: Problems and possibilities. Issues in Early Education, 3(42), 134-143. https://doi.org/10.26881/pwe.2018.42.14

Rochovská, I. et al. (2021). Interpretácia umeleckého diela v predprimárnom vzdelávaní [Interpretation of Artwork in Pre-school Education]. 03401 Ružomberok, SLOVAKIA Verbum.

Rochovská, I., \& Krupová, D. (2016). Visual art in nursery schools. Multidisciplinary Journal of School Education, 2(2016), 69-87.

Ruismäki, H., \& Juvonen, A. (2008). Kindergarten teacher students as art educators, Spaces of Creation, 9, 46-59.

Sellier, J. (1977). Test of Creative Thinking - Torrance. Psychologie, 86(1977).

Švábová, B. (2019). Active game activities of children in pre-primary education. Revue Internationale des Sciences Humanities et Naturalles, 2(2019), 27-44.

Toivanen, T., Halkilahti, L., \& Ruismäki, H. (2013). Creative pedagogy - Supporting children's creativity through drama. The European Journal of Social \& Behavioural Sciences, 7(4), 11681179. https://doi.org/10.15405/ejsbs.96

$\mid \begin{aligned} & \text { PROBLEMS } \\ & \text { OF EDUCATION } \\ & \text { IN THE } 21^{\text {st }} \text { CENTURY } \\ & \text { Vol. } 79, \text { No. 6, } 2021\end{aligned}$

969 
Ivana ROCHOVSKÁ, Božena ŠVÁBOVÁ. The use of the interpretation of works of art in pre-school education

PROBLEMS

OF EDUCATION

IN THE $21^{\text {st }}$ CENTURY

Vol. 79, No. 6, 2021

970

Tomas, I. (2019). Searching for agreement. On the difficulty in assessing artworks - Own research report. The New Educational Review, 55(1), 121-131. https://doi/10.15804/TNER.2019.55.1.10

Yang, W., \& Chen, M. (2021). Problems and development strategies for art education in kindergarten in the new media era. Journal of Physics: Conference Series, 1852(4).

Zimmerman, E., \& Zimmerman, L. (2000). Art education and early childhood education: The young child as creator and meaning maker within a community context. Young Children, 55(6), 87-92. http://www.jstor.org/stable/42728610

Received: September 28, 2021

Accepted: November 29, 2021

Cite as: Rochovská, I., \& Švábová, B. (2021). The use of the interpretation of works of art in pre-school education. Problems of Education in the $21^{\text {st }}$ Century, 79(6), 956-970. https://doi.org/10.33225/pec/21.79.956

Ivana Rochovská

(Corresponding author)
$\mathrm{PhD}$, Associate Professor, Faculty of Education, Juraj Páleš Institute in Levoča, Catholic University in Ružomberok, Bottova 15, 05401 Levoča, Slovakia.

E-mail: ikrupova@gmail.com

ORCID: https://orcid.org/0000-0001-9346-7993

\section{Božena Švábová}

PhD, Professor, Special Assistant, Faculty of Education, Juraj Páleš Institute in Levoča, Catholic University in Ružomberok, Bottova 15, 05401 Levoča, Slovakia.

E-mail: bozenasvab@gmail.com 